\title{
KEEPING COOL IN ACUTE LIVER FAILURE: RATIONALE FOR THE USE OF MILD HYPOTHERMIA
}

Javier Vaquero, Christopher Rose, Roger F. Butterworth

Neuroscience Research Unit, Hôpital Saint-Luc (C.H.U.M.), 1058 St Denis street, Montreal, QC, Canada H2X 3J4

\section{ABSTRACT}

Encephalopathy, brain edema and intracranial hypertension are neurological complications responsible for substantial morbidity/mortality in patients with acute liver failure (ALF), where, aside from liver transplantation, there is currently a paucity of effective therapies. Mirroring its cerebro-protective effects in other clinical conditions, the induction of mild hypothermia may provide a potential therapeutic approach to the management of ALF. A solid mechanistic rationale for the use of mild hypothermia is provided by clinical and experimental studies showing its beneficial effects in relation to many of the key factors that determine the development of brain edema and intracranial hypertension in ALF, namely the delivery of ammonia to the brain, the disturbances of brain organic osmolytes and brain extracellular amino acids, cerebro-vascular haemodynamics, brain glucose metabolism, inflammation, subclinical seizure activity and alterations of gene expression. Initial uncontrolled clinical studies of mild hypothermia in patients with ALF suggest that it is an effective, feasible and safe approach. Randomized controlled clinical trials are now needed to adequately assess its efficacy, safety, clinical impact on global outcomes and to provide the guidelines for its use in ALF.

Keywords Hypothermia; Acute liver failure; Brain edema; Ammonia

Abbreviations ALF, acute liver failure; CBF, cerebral blood flow; ICP, intracranial pressure; IL-1b, interleukin-1beta; TNF-alpha, tumour necrosis factor-alpha; IL-6, inteleukin-6

\section{INTRODUCTION}

Hepatic encephalopathy and brain edema leading to intracranial hypertension are two major complications in patients with acute liver failure (ALF). Whereas the former defines the syndrome of ALF, the development of high intracranial pressure (ICP) is associated with high mortality [1]. The current view embraces both entities as parts of the same spectrum of alterations, and recognizes central pathophysiologic roles for ammonia and astrocyte swelling (Fig. 1) [2]. Risk factors for developing intracranial hypertension and brain herniation include a short interval between the onset of jaundice and brain dysfunction, worsening of encephalopathy, and arterial ammonia concentrations $>150 \mathrm{mM}[3]$ and [4]. 


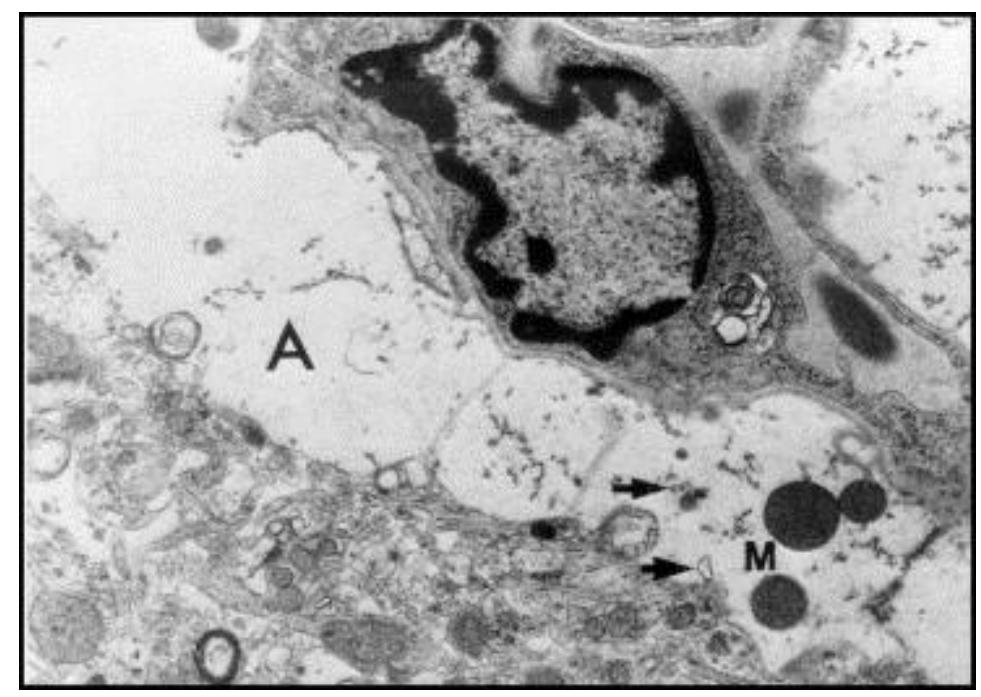

Fig. 1. Electron micrograph of a section of cerebral cortex from a patient who died with acute liver failure. Perivascular astrocytes (A) are markedly swollen and vacuolar. Endoplasmic reticulum is dilated (arrow) and mitochondria $(\mathrm{M})$ are also swollen (original magnification $\times 6000$ ). From Kato et al. [168], with permission.

Accumulating evidence suggests that mild hypothermia $\left(32-35^{\circ} \mathrm{C}\right)$ can effectively treat the neurological complications of ALF. In contrast to other alternatives, its ease of application and low cost opens this therapy to hospitals throughout the world, many of which do not benefit from the liver transplantation option. At a time when mild hypothermia is increasingly being used in ALF patients in uncontrolled studies, this review summarizes the rationale that supports its use and calls for the need for controlled clinical trials. In the studies reviewed here, hypothermia was induced by cooling the whole body, as selective brain cooling is difficult in adults [5].

\section{USE OF HYPOTHERMIA AS A BRAIN-PROTECTANT IN NEUROLOGICAL AND SYSTEMIC DISORDERS}

\section{Current clinical use of hypothermia}

The modern clinical use of hypothermia commenced in 1950, when Bigelow demonstrated its neuro-protective properties during cardiac surgery [6] and [7]. This hallmark discovery allowed the performance of open-heart surgical procedures without the neurological sequellae of brain ischemia, and prompted the investigation of hypothermia in other conditions. In addition to cardiac surgery, hypothermia is now used during some neurosurgical procedures, mainly those involving aneurysms [8].

Cardiac arrest and traumatic brain injury are two conditions, where hypothermia is also used. The American Heart Association includes hypothermia in the treatment of unconscious adult patients with spontaneous circulation after out-of-hospital cardiac arrest [9], based on two recent randomized controlled trials [10] and [11]. The utilization of hypothermia in traumatic brain injury is controversial [12] and [13], despite promising experimental studies [14], [15], [16] and [17]. Beneficial effects were found in single-center clinical trials [18], [19] and [20], but a recent multicenter study failed to show any benefits in survival or neurological outcome [21]. Intercenter differences, however, could have influenced the results [22]. Despite the controversy, hypothermia is often used in these patients [8], as its efficacy to reduce ICP is well established [18], [20], [21], [23] and [24]. Hypothermia has also been clinically used in acute cerebrovascular accidents [25], [26], [27], [28] and [29] or subarachnoid haemorrhages [30], but its benefit is unclear as most studies are uncontrolled. 
Vaquero, J., Rose, C. \& Butterworth, R.F., 2005. Keeping cool in acute liver failure: rationale for the use of mild hypothermia. Journal of Hepatology, 43(6), p.1067-1077.

\section{Mechanisms of action of hypothermia in systemic disorders}

A brief examination of the mechanisms of hypothermia in systemic disorders may help to understand its benefit in ALF.

The brain needs a constant supply of glucose and oxygen. In general, the activities of brain energy-producing pathways decrease 2- to 4 -fold by a $10^{\circ} \mathrm{C}$ decrease of temperature [31]. The reduction of energy demands during low energy supply was the initial rationale for using hypothermia [6] and [32]. Accordingly, induction of hypothermia during brain ischemia decreases the histological damage in several experimental models [15], [33], [34] and [35]. In contrast to anaesthetics, which only decrease brain energy requirements associated with electrophysiological activity [36] and [37], hypothermia decreases these requirements even during electroencephalographic silence, suggesting that it affects energy processes associated with both basic cellular functions and neurotransmission [38].

The reduction of brain energy demand during ischemia is not the sole mechanism of action of hypothermia. Delayed induction of hypothermia - after the ischemic or traumatic insult - provided brain protection in various experimental models [16], [35], [39], [40] and [41]. Reductions of only $2-4{ }^{\circ} \mathrm{C}$, which produce relatively small decreases of brain metabolism, also have protective effects. The protection afforded by similar suppressions of brain metabolism using anaesthetic agents, in contrast, is less clear [42]. Finally, hypothermia can be effective despite a concomitant depletion of brain energy stores or accumulation of lactate [15] and [43]. These observations suggest that hypothermia affects other steps in addition to the disturbance of energy metabolism.

The alteration of cellular ionic homeostasis plays a major role in brain ischemia and neurotrauma. Due to energy failure, the energy-dependent membrane ionic pumps, the voltage-dependent ion channels and others become progressively altered, and result in disturbance of ionic homeostasis, which ultimately leads to cell swelling, activation of proteolysis, lipid degradation, mitochondrial dysfunction and free radical generation. A release of excitatory neurotransmitters worsens further this scenario, e.g. via the influx of sodium and/or calcium after the binding of glutamate to NMDA receptors. Hypothermia may influence several steps of this cascade of events. For example, it may have a 'membrane-stabilizing' effect, improving the altered permeability to ions [44]. Hypothermia also prevents the extracellular increase of brain excitatory neurotransmitters in brain ischemia [45], [46], [47], [48], [49], [50] and [51] and neurotrauma [20] and [52]. The extracellular levels of glutamate correlate with the formation of free radicals [52] and [53], which can influence signalling pathways or cause direct damage of cellular components. Importantly, hypothermia prevents the elevation of hydroxyl radical-derived compounds in the brain of rats following cerebral ischemia or traumatic brain injury [52] and [54], suggesting another potential effect.

Apoptosis and inflammation are also potential targets of hypothermia. Hypothermia may decrease the number of apoptotic cells by the modulation of apoptotic pathways, such as the release of cytochrome-C or the activation of caspases [55], [56], [57], [58], [59] and [60]. Hypothermia may also reduce the infiltration of brain tissue by polymorphonuclear cells [60], [61], [62] and [63], as well as the production of leukotrienes [64], nitric oxide [65], [66], [67] and [68] and pro-inflammatory cytokines [69]. Lower concentrations of IL-1 $\beta$ in cerebrospinal fluid [20] and IL-6 in internal jugular vein [70] have been noted in neurotrauma patients treated with hypothermia. Finally, hypothermia ameliorates the alteration of blood-brain barrier permeability in animal models of brain ischemiareperfusion and traumatic brain injury [71], [72], [73] and [74].

These actions of hypothermia may attenuate brain edema and intracranial hypertension. In addition, the rapid decrease of ICP-induced by hypothermia [18], [20], [21], [23] and [24] suggests that the reduction of cerebral blood flow (CBF) and volume may account to a large part for the effect of hypothermia on ICP. The reduction of ICP has, in turn, beneficial effects on the preservation of brain tissue perfusion and blood-brain barrier integrity.

The final publication is available at http://dx.doi.org/10.1016/i.jhep.2005.05.039 
Vaquero, J., Rose, C. \& Butterworth, R.F., 2005. Keeping cool in acute liver failure: rationale for the use of mild hypothermia.

Journal of Hepatology, 43(6), p.1067-1077.

MECHANISMS RESPONSIBLE FOR THE PROTECTIVE EFFECT OF MILD HYPOTHERMIA IN ALF

The pathophysiology of brain edema and intracranial hypertension in ALF differs from the previous disorders. Mild hypothermia, however, is effective for preventing the neurological complications of ALF in experimental studies [75], [76], [77] and [78]. The effects of hypothermia on the major factors considered to determine brain edema and intracranial hypertension in ALF have been the focus of both clinical and experimental studies (summarized in Table 1).

Table 1. Potential mechanisms of action of hypothermia for preventing brain edema and intracranial hypertension in ALF

\begin{tabular}{|c|c|c|}
\hline Physiological target & Potential actions & References \\
\hline \multirow{5}{*}{ Ammonia } & $\downarrow$ Brain concentration of ammonia & {$[79]$} \\
\hline & $\downarrow$ Arterial concentration of ammonia & {$[80]$ and $[81]$} \\
\hline & $\downarrow$ Production of ammonia by intestinal bacteria & [83] \\
\hline & $\downarrow$ Renal release of ammonia to the blood & {$[85]$} \\
\hline & $\downarrow$ Proteolysis & {$[86]$} \\
\hline \multirow{2}{*}{ Brain osmolarity } & Prevention of brain lactate and alanine accumulation & [96] \\
\hline & Prevention of changes of brain organic solutes & [97] \\
\hline \multirow{3}{*}{ Brain extracellular space } & $\downarrow$ Accumulation of glutamate & [76] \\
\hline & $\downarrow$ Of glutamate-induced astrocyte swelling & [107] \\
\hline & $\downarrow$ Accumulation of lactate & {$[77]$} \\
\hline \multirow{3}{*}{$\begin{array}{l}\text { Cerebro-vascular } \\
\text { haemodynamics }\end{array}$} & Restoration of cerebro-vascular autoregulation & [119] \\
\hline & $\downarrow$ Of cerebral blood flow and cerebral uptake of ammonia & {$[80]$ and $[81]$} \\
\hline & Prevention of cerebral hyperemia & [78] and [120] \\
\hline \multirow[b]{2}{*}{ Brain glucose metabolism } & $\downarrow$ cerebral metabolic rate of glucose and oxygen & [80] and [81] \\
\hline & $\begin{array}{l}\text { Amelioration of increased de novo synthesis of lactate and } \\
\text { alanine }\end{array}$ & [96] \\
\hline Inflammation & $\begin{array}{l}\downarrow \text { Of arterial concentration and brain production of } \\
\text { cytokines }\end{array}$ & [81] and [120] \\
\hline Subclinical seizure activity & $\downarrow$ Seizure activity (in experimental models of epilepsy) & [133] and [134] \\
\hline
\end{tabular}

The final publication is available at http://dx.doi.org/10.1016/i.jhep.2005.05.039 


\section{Ammonia delivery to the brain and Arterial ammonia concentrations}

Exposure of the brain to high levels of ammonia is a consistent feature in ALF, where the brain-to-blood concentration ratio of ammonia (normal 2:1) may be as high as 8:1 [2]. The reduction of brain ammonia could be a major mechanism of hypothermia in ALF. Forty years ago, Schenker and Warren tested the toxicity of ammonium chloride administered intravenously, and found that the LD50 for normothermic $\left(38.8^{\circ} \mathrm{C}\right)$ mice was almost double than for hypothermic $\left(27.9^{\circ} \mathrm{C}\right)$ mice [79]. The increase of brain ammonia was less in hypothermic mice as early as $20 \mathrm{~s}$ after injection, suggesting that decreased brain ammonia uptake was due to decreased CBF.

Mild hypothermia decreases the arterial ammonia concentrations in patients with ALF [80] and [81] or urea-cycle defects [82]. In addition to the effect on $\mathrm{CBF}$, therefore, hypothermia could reduce ammonia delivery to the brain by reducing its arterial concentration. Hypothermia $\left(30^{\circ} \mathrm{C}\right)$ decreases bacterial ammonia production in fecal samples and the levels of ammonia in the inferior mesenteric vein of dogs, with the capacity of liver to detoxify ammonia being preserved [83] and [84]. Additional mechanisms include the reduction of ammonia release by the kidney [85] and of proteolysis [86]. Although arterial ammonia levels were not reduced by hypothermia in some experimental rat models [75], [76] and [78], the prior observations point to reduction of ammonemia as an operative mechanism of hypothermia in ALF.

\section{Brain osmotic disturbances}

The brain in ALF is characterized by a profound osmotic alteration, similar to that observed in pure hyperammonemic models [87]. Since the brain cannot synthesize urea, detoxification of ammonia relies almost entirely on glutamine synthetase localized in astrocytes [88]. An increase of brain glutamine is a major feature in hyperammonemia or ALF [87], [89], [90], [91], [92], [93] and [94], and inhibition of glutamine synthesis attenuates ammonia-induced brain edema [87] and [89]. The osmotic effects of glutamine may partly explain the selective astrocytic swelling in ALF.

The prevention of brain edema by hypothermia in hyperammonemia or ALF, however, is not accompanied by reduction of brain glutamine [78] and [92], similar to findings with indomethacin [95]. These observations challenge the notion of glutamine as the major determinant of brain edema in ALF. Glutamine, however, is not the only organic osmolyte or solute altered in ALF; increases of glucose, alanine and lactate and decreases of glutamate, aspartate, myo-inositol and taurine have also been noted [90], [91], [92] and [93]. Increases of brain lactate and alanine correlate better than glutamine with the grade of encephalopathy and brain edema in hepatic devascularized rats [91] and [92]. In this model, mild hypothermia is highly effective in preventing increases of alanine and lactate, and alterations of glutamate, aspartate, myo-inositol and taurine [96] and [97] (Table 2). Hypothermia, therefore, appears to improve the brain osmotic disturbance of ALF. 
Vaquero, J., Rose, C. \& Butterworth, R.F., 2005. Keeping cool in acute liver failure: rationale for the use of mild hypothermia. Journal of Hepatology, 43(6), p.1067-1077.

Table 2. Effect of mild hypothermia $\left(35^{\circ} \mathrm{C}\right)$ on the concentrations of organic osmolytes in the brain of rats with acute liver failure (ALF) due to hepatic devascularization

\begin{tabular}{lccc}
\hline \multicolumn{5}{c}{ Sham-operated controls ALF normothermic (coma stage) ALF hypothermic } \\
& $\mathrm{n}(9)$ & $\mathrm{n}(9)$ & $\mathrm{n}(10)$ \\
\hline Glutamine & $5.20 \pm 0.31$ & $23.03 \pm 1.61^{*}$ & $26.12 \pm 2.40^{*}$ \\
myo-inositol $6.32 \pm 0.48$ & $3.66 \pm 0.30^{*}$ & $5.27 \pm 0.44^{*}, \dagger$ \\
Taurine & $5.17 \pm 0.31$ & $3.45 \pm 0.27^{*}$ & $5.29 \pm 0.51 \dagger$
\end{tabular}

Modified from Zwingmann et al. [97]. Concentrations of metabolites were calculated by integration of the respective peaks in $1 \mathrm{H}-\mathrm{NMR}$ spectra of brain extracts obtained from sham-operated control rats, rats with ALF maintained at $37^{\circ} \mathrm{C}$ at coma stages, and rats with ALF maintained at $35^{\circ} \mathrm{C}$ (time-matched to ALF-37 coma). Values (mean $\pm \mathrm{SD}$ ) are given in $\mu \mathrm{mol} / \mathrm{g}$ wet weight. Number of animal indicated in parenthesis. * Significantly different from controls $(\mathrm{P}<0.05$, two-way ANOVA and post hoc Tukey test). †Significantly different between hypothermic and normothermic ALF rats $(\mathrm{P}<0.05$, two-way ANOVA and post hoc Tukey test).

\section{Extracellular brain concentrations of amino acids}

The composition of the brain extracellular fluid is altered in ALF. Using brain microdialysis in rats with ALF, we observed extracellular increases of 11 out of 13 amino acids at coma stages in normothermic animals. These increases included neurotransmitter amino acids, organic osmolytes, branched chain and aromatic amino acids (Fig. 2, A-D). Increases of 6 of the 11 (55\%) amino acids were attenuated (Ala, Phe) or normalized (Glu, Asp, Gly, Trp) in rats maintained hypothermic $\left(\sim 35^{\circ} \mathrm{C}\right)$. Some increases, however, were unchanged (Gln, Tau, Val, Tyr) or even enhanced (Leu). These observations may provide new insights into the pathogenesis of brain edema in ALF.

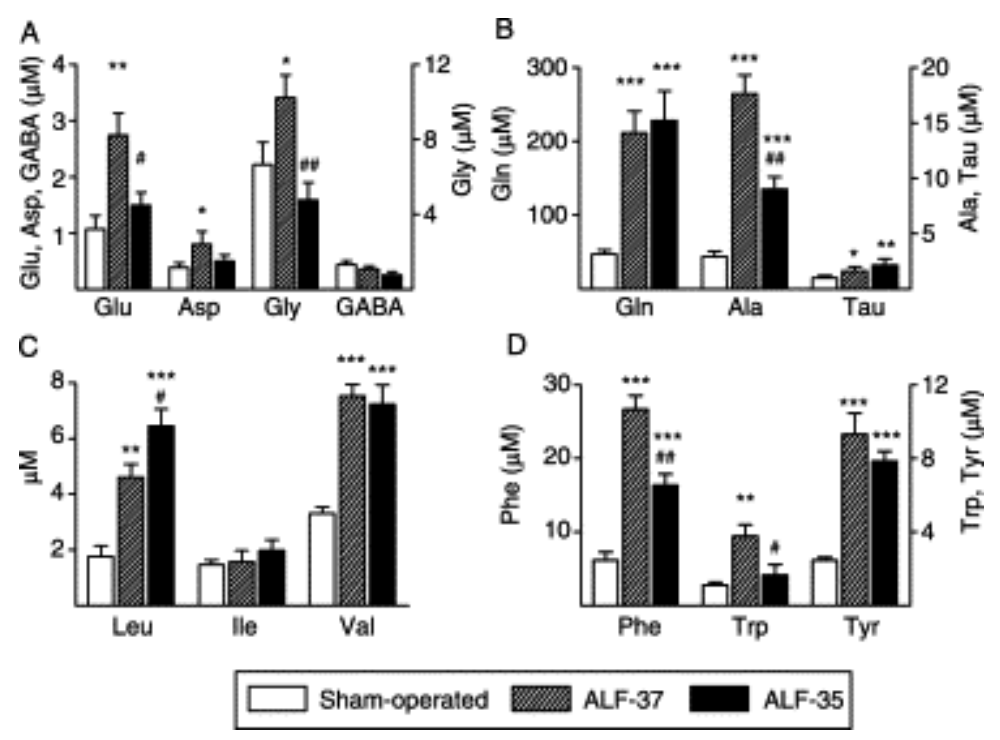

Fig. 2. Extracellular brain concentrations of amino acids in sham-operated rats, rats with ALF maintained at normothermia (ALF-37) and rats with ALF maintained mildly hypothermic $\left(35^{\circ} \mathrm{C}, \mathrm{ALF}-35\right)$ (n=6/group). Panels show neurotransmitter amino acids (A), amino acids with osmotic properties (B), branched chain (C) and aromatic (D) amino acids. An end-to-side portacaval shunt or sham operation were performed in male 
Vaquero, J., Rose, C. \& Butterworth, R.F., 2005. Keeping cool in acute liver failure: rationale for the use of mild hypothermia. Journal of Hepatology, 43(6), p.1067-1077.

Sprague-Dawley rats followed $24 \mathrm{~h}$ later by stereotaxic implantation of a guide cannula in cerebral cortex. At $48 \mathrm{~h}$, hepatic artery ligation or sham operation were performed to induce liver failure. Extracellular brain concentrations of amino acids $(\mu \mathrm{M})$ were measured by HPLC with fluorescence detection in brain microdialysate from ALF-37 rats at coma stages of encephalopathy or at parallel time-points in the other groups, as previously described [76]. Bars represent mean \pm SEM. Abbreviations: Glu, glutamate; Asp, aspartate; Gly, glycine; GABA, $\gamma$-amino butyric acid; Gln, glutamine; Ala, alanine; Tau, taurine; Leu, leucine; Ile, isoleucine; Val, valine; Phe, phenylalanine; Trp, tryptophan; Tyr, tyrosine. ${ }^{*} \mathrm{P}<0.05$ vs. Sham, ${ }^{* *} \mathrm{P}<0.01$ vs. Sham, ${ }^{* * *} \mathrm{P}<0.001$ vs. Sham. $\# \mathrm{P}<0.05$ vs. ALF-37, \#\#P<0.01 vs. ALF-37.

Increased extracellular brain glutamate is a common finding in ALF [98], [99], [100] and [101]. Potential explanations include impairment of its clearance [102] and [103] and deregulation of calcium-dependent glutamate release from astrocytes [104]. Because increased extracellular glutamate causes astrocyte swelling in vitro [105] and [106], the prevention of the increase of extracellular glutamate by hypothermia may reduce brain edema in ALF [76]. Downstream steps may also be affected, as hypothermia $\left(24{ }^{\circ} \mathrm{C}\right)$ resulted in a $74 \%$ reduction of glutamate-induced swelling in cultured astrocytes, an effect associated with decreased astrocytic uptake of $\mathrm{K}+[107]$. The binding of glutamate to NMDA receptors leads to the production of nitric oxide, which may be involved in the pathogenesis of brain edema in ALF [108] and [109]. Interestingly, the increase of glycine, a positive allosteric modulator of NMDA receptors, was also prevented by hypothermia (Fig. 2A). Increases of aromatic amino acids, precursors of monoamine neurotransmitters [110], were attenuated by hypothermia (Fig. 2D). The lack of effect of hypothermia on branched chain amino acids (Fig. 2C), in contrast, diminishes their potential relevance to the development of brain edema in ALF.

\section{Cerebrovascular haemodynamics}

Loss of cerebrovascular autoregulation and development of cerebral hyperemia, described in patients with advanced ALF [111], [112], [113], [114] and [115], are relevant to the pathogenesis of brain edema and intracranial hypertension [116]. Loss of cerebrovascular autoregulation may cause luxury perfusion or hypoxia during increases or decreases of systemic arterial pressure, respectively. Cerebral hyperemia is associated with brain edema and mortality in ALF [113] and [117]. The mechanisms by which cerebral hyperemia enhances brain edema and ICP in ALF have been reviewed by Larsen and Wendon [116]. Briefly, small increases of blood volume in the non-compliant brain cause increases of ICP, which may result in brain hypoxia. Cerebral hyperemia may also increase hydrostatic pressure in brain capillaries, and worsen brain osmotic disturbances by increasing ammonia delivery; both events would favour the movement of water into the brain.

Both cerebral hyperemia and loss of autoregulation are corrected by hypothermia. In the portacaval-shunted rat receiving an ammonia infusion, where CBF and brain edema are intimately connected [95] and [118], the reduction of brain edema by hypothermia was accompanied by the prevention of cerebral hyperemia [78]. Similarly, studies in patients with ALF and refractory intracranial hypertension showed that the rapid reduction of ICP after starting mild hypothermia was paralleled by decreases of CBF and cerebral uptake of ammonia [80] and [81]. Mild hypothermia also restored the cerebrovascular autoregulation and the normal vasodilatory response of brain vasculature to carbon dioxide [119], and it was highly effective in preventing the increases of CBF that commonly occur during liver transplantation surgery for ALF [120]. Modulation of CBF, therefore, seems a major protective mechanism of hypothermia in ALF.

\section{Brain glucose metabolism}

Brain glucose metabolism is disturbed in ALF. Increased brain lactate is common in animal models [77], [93], [94] and [121], and peaks of lactate in brain microdialysate preceding surges of ICP have been described in patients with ALF [98]. Increased brain lactate correlated with worsening encephalopathy and intracranial hypertension in experimental models [92] and [121], and it was due to increased de novo synthesis from circulating glucose. This observation suggests decreased oxidation of pyruvate [92], in accordance with inhibition of alpha-ketoglutarate dehydrogenase and stimulation of the glycolytic enzyme phosphofructokinase by ammonia in vitro [122] and [123].

The final publication is available at http://dx.doi.org/10.1016/i.jhep.2005.05.039 
The effects of hypothermia $\left(32-33^{\circ} \mathrm{C}\right)$ on brain glucose metabolism were studied by Jalan et al. in patients with ALF and uncontrolled ICP [80]. These patients presented low cerebral metabolic rates for oxygen and glucose at baseline, but hypothermia reduced such rates by 75 and $>90 \%$, respectively, suggesting overall improvement of glucose oxidation. In support of this, mild hypothermia $\left(35^{\circ} \mathrm{C}\right)$ prevented the increase of lactate in the cerebrospinal fluid of ALF rats [77], as well as other alterations of brain glucose metabolism—studied using [1-13C]glucose and 1H-13CNMR spectroscopy [96] (Fig. 3). Hepatic devascularization in normothermic animals increased the brain total ( $\uparrow$ $170 \%$ ) and 13C-labeled ( $\uparrow 447 \%$ ) lactate at coma stages compared to sham-operated controls. Induction of hypothermia attenuated ( $\uparrow 131 \%$ ) and completely prevented the increases of total and 13C-labeled lactate, respectively. Similar changes were observed for alanine. These effects of hypothermia, therefore, reside in its ability to prevent the de novo synthesis of these compounds in the brain.

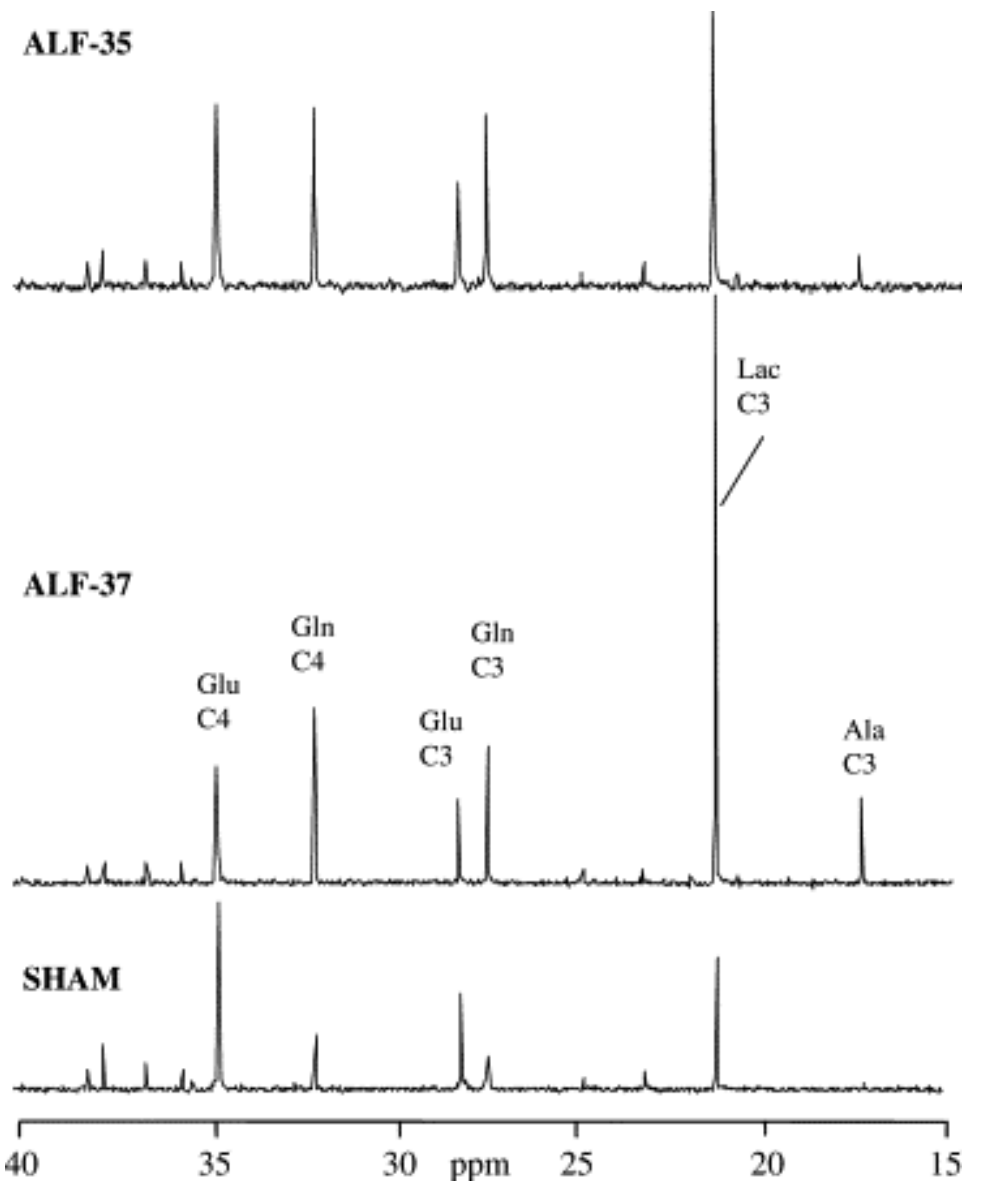

Fig. 3. Effects of hypothermia on 13C-NMR spectra of brain extracts from rats with ALF. Sham-operated rats were compared with rats with ALF due to hepatic devascularization maintained at $37^{\circ} \mathrm{C}$ (ALF-37) or $35^{\circ} \mathrm{C}$ (ALF-35). Hepatic devascularization was achieved by constructing a portacaval anastomosis followed $24 \mathrm{~h}$ later by hepatic artery ligation. [1-13C] Glucose $(200 \mathrm{mg} / \mathrm{kg}$ ip, Cambridge Isotope Laboratories) was administered $15 \mathrm{~min}$ before decapitation. The figure shows the distribution of the label from the 1st carbon position of glucose among diverse glucose-derived metabolites. Peak assigments: Glu, glutamate; Gln, glutamine; Lac, lactate; Ala, alanine. [Adapted from Chatauret et al. [96]].

\section{Inflammation}

Clinical and experimental evidence links inflammation to the development of neurological complications in ALF [124], [125] and [126]. Correlations between decreases of cytokines, such as interleukin-1b and interleukin-6, and a 
Vaquero, J., Rose, C. \& Butterworth, R.F., 2005. Keeping cool in acute liver failure: rationale for the use of mild hypothermia. Journal of Hepatology, 43(6), p.1067-1077.

decrease of ICP and CBF have been reported in patients with ALF [127] and [128]. Cytokines could influence CBF and may directly induce astrocyte swelling [129] and [130].

As in ischemic and traumatic brain injury, modulation of inflammation could be a mechanism of action of hypothermia in ALF. Arterial levels and the brain efflux of IL-1b were lower in patients listed for liver transplantation in whom hypothermia was induced [120]. The prevention of cerebral hyperemia and ICP surges during liver transplantation was associated with attenuation of the increases of circulating IL- $1 \mathrm{~b}$, present in patients operated at normothermia [120]. Similarly, the reduction of ICP by mild hypothermia in ALF patients with uncontrolled intracranial hypertension was accompanied by a reduction of both the arterial concentrations and the brain flux of TNF-alpha, IL-1b and IL-6 [81].

\section{Subclinical-seizure activity}

Prevention of subclinical seizure activity by a prophylactic infusion of phenytoin may be beneficial for reducing brain edema in ALF [131], although a recent clinical trial noted no benefit [132]. Seizures can aggravate brain edema and intracranial hypertension by increasing brain metabolism, but they can also be the result of ICP surges. Hypothermia reduces seizure activity in experimental models of epilepsy [133] and [134], and could provide a potential mechanism in ALF.

\section{Gene expression}

The expression of genes involved in basic cellular processes in the brain is altered in ALF. Many of these altered genes are predominantly astrocytic, such as the glutamate transporter GLT-1, glial fibrillary acidic protein, and the astrocytic/endothelial cell glucose transporter GLUT-1 [135], [136] and [137]. Other genes include the peripheraltype benzodiazepine receptor, $\mathrm{Cu}, \mathrm{Zn}$-superoxide dismutase and heme oxygenase-1 [138], [139] and [140]. Mild hypothermia in rats with experimental ALF corrects the expression of many of these genes [141], but it remains to be elucidated which of these genes are involved in hypothermia's preventive effect on brain edema in ALF.

\section{THERAPEUTIC IMPLICATIONS}

Elevation of the head of the bed, hyperventilation, administration of mannitol \pm fluid removal with renal replacement methods, and the administration of barbiturates constitute the standard treatments for episodes of high ICP in ALF [142]. Unfortunately, these treatments are not completely effective and may be contraindicated. Beneficial effects of $\mathrm{N}$-acetylcysteine [143] and [144], propofol [145], phenytoin [131], indomethacin [146], or hypertonic saline [147] have been reported in single-center studies, and (bio)-artificial liver assist devices may also decrease ICP [148] and [149]. The efficacy of these interventions, however, still needs to be fully validated, and some are restricted to a few specialized centres. These considerations underline the need to find more effective and easier-touse therapies.

Induction of mild hypothermia has the potential to be one such therapy, but its clinical use in ALF has been limited so far to small, uncontrolled studies [80], [120] and [150]. Although these studies were performed in two conditions of difficult management and high mortality, beneficial effects of hypothermia were observed. Firstly, in the episode of intracranial hypertension unresponsive to conventional therapies. Seven patients with ALF presenting such episodes were treated with mild hypothermia [80], and striking reductions of ICP were observed in all cases. In 3 patients who were not candidates for liver transplantation, rewarming was associated with a rapid rise of ICP and death shortly thereafter. The remaining 4 patients, in whom mild hypothermia was maintained until a donor organ was available and during transplantation surgery, all survived to liver transplantation. These encouraging results have been recently confirmed by the same group in a new series of 14 similar patients (Fig. 4) [81].

The final publication is available at http://dx.doi.org/10.1016/i.jhep.2005.05.039 
Vaquero, J., Rose, C. \& Butterworth, R.F., 2005. Keeping cool in acute liver failure: rationale for the use of mild hypothermia. Journal of Hepatology, 43(6), p.1067-1077.

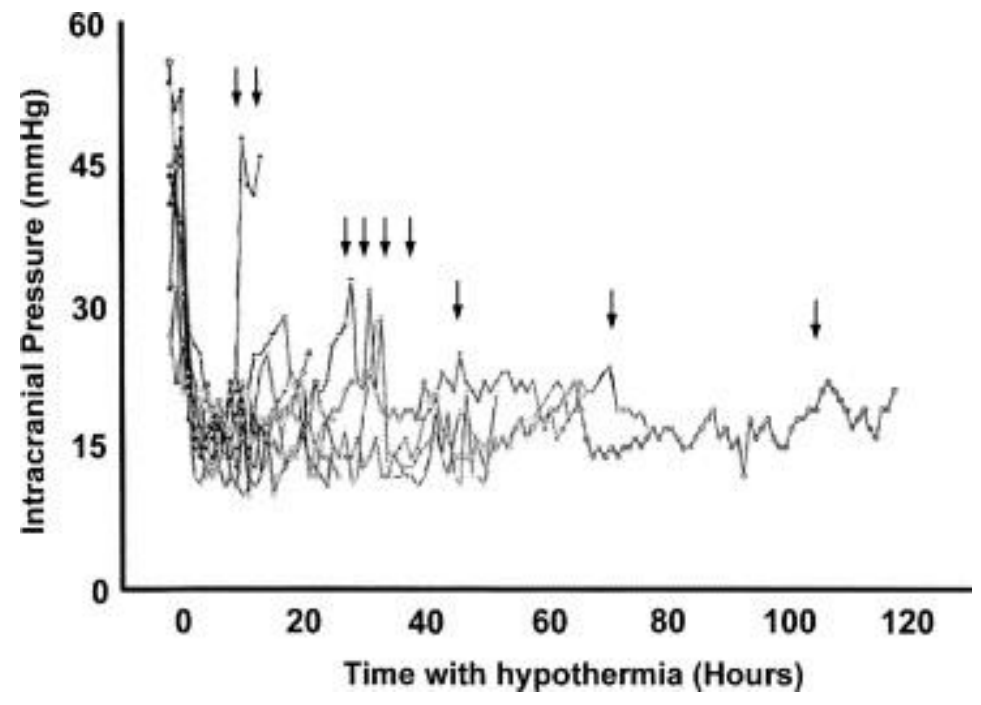

Fig. 4. Effects of hypothermia $\left(32^{\circ} \mathrm{C}\right)$ on intracranial pressure in 14 patients with ALF and uncontrolled intracranial hypertension. Arrows indicate additional treatment with mannitol in 5 of the 14 patients. [Adapted from Jalan et al. [81]].

The second clinical condition where hypothermia has been explored was the surges of ICP during emergency liver transplantation, which are common during the dissection and reperfusion phases of the operation [151] and [152]. In a new study, the 11 patients with ALF transplanted under normothermic conditions presented significant increases of ICP during surgery, many of them requiring treatment with thiopentone [120]. In contrast, no increase of ICP was observed in the patients in whom mild hypothermia was maintained during surgery.

An aspect that deserves to be highlighted is the effect of hypothermia on systemic haemodynamics. Due to the loss of cerebrovascular autoregulation, the use of vasopressors in ALF can lead to increases of CBF [153] and [154] and may worsen intracranial hypertension. In the prior clinical studies, mild hypothermia improved the hyperdynamic circulation and hypotension characteristics of ALF, reflected by a reduced requirement of vasopressor medication [80] and [81]. Because it also restores cerebrovascular autoregulation [119], hypothermia may facilitate the difficult haemodynamic management of these patients.

These beneficial effects led to evaluate a prophylactic use of mild hypothermia in patients with ALF at risk for developing increased ICP [142]. Why, then, is the clinical use of mild hypothermia in ALF restricted to isolated studies in a few centres?

\section{Adverse effects and Unresolved issues of mild hypoth ermia in ALF}

Potential adverse effects of mild hypothermia (reviewed previously in [155] and [156]) include shivering, cardiac complications (arrhythmias, myocardial ischemia), alterations of fluid and electrolyte homeostasis, metabolic alterations (hyperglycemia, hyperlactatemia), infections (mainly respiratory) and coagulopathy. In general, the risk of complications increases with the duration and degree of hypothermia, mainly with core temperatures below $32{ }^{\circ} \mathrm{C}$. In ALF, however, small decreases of temperature may be effective [157]. Individualized 'tailoring' of the therapy, thus, could avoid unnecessary complications. Anaesthetic management during the induction of hypothermia and adequate rewarming are also key factors to avoid complications and to determine the success of the therapy.

The potential increase of infections and coagulopathy probably explains the reluctance to use mild hypothermia in ALF. A higher rate of infection and worsening of coagulation have been reported in some clinical studies of hypothermia in neurotrauma [158], [159] and [160]. These complications, however, have not constituted a major problem in the majority of randomized studies [19], [20], [24] and [161], have been absent so far in ALF patients 
Vaquero, J., Rose, C. \& Butterworth, R.F., 2005. Keeping cool in acute liver failure: rationale for the use of mild hypothermia. Journal of Hepatology, 43(6), p.1067-1077.

treated with hypothermia [80], [81], [119] and [120] and, importantly, they can be prevented and managed. New therapies, such as recombinant factor VIIa [162] or granulocyte colony-stimulating factor [163] could also be helpful.

In ALF, the effect of hypothermia on the diseased liver is a matter of interest. Studies suggest that hypothermia reduces liver injury [164], [165] and [166], but it may impair liver regeneration [167]. Further research will be needed to clarify these issues.

In summary, a large body of experimental evidence and initial clinical studies suggest that mild hypothermia is effective in the treatment of the neurological complications of ALF. Due to the multi-systemic nature of ALF, therapies aimed at specific complications are unlikely to have a major impact on final outcome. Although the multiple neural mechanisms and systemic effects of hypothermia advise caution, they also imply its potential to significantly influence the natural history of ALF. As for any therapy, the balance between adverse and beneficial effects needs to be evaluated in each subgroup of patients that may benefit from it. Randomized controlled clinical trials are now required to confirm the safety and efficacy of mild hypothermia in ALF, to critically assess its effects on global outcomes, and to provide adequate guidelines for its use.

\section{ACKNOWLEDGEMENTS}

This work was supported by a grant from the Canadian Institutes of Health Research (CIHR). J Vaquero was supported by a grant from Fondo de Investigacion Sanitaria (Instituto de Salud Carlos III, Spain). C Rose was supported by a CIHR fellowship.

\section{REFERENCES}

[1] A.J. Ware, A.N. D'Agostino, B. Combes Cerebral edema: a major complication of massive hepatic necrosis Gastroenterology, 61 (1971), pp. 877-884

[2] R.F. Butterworth Molecular neurobiology of acute liver failure Semin Liver Dis, 23 (2003), pp. 251-258

[3] J.G. O'Grady, S.W. Schalm, R. Williams Acute liver failure: redefining the syndromes Lancet, 342 (1993), pp. 273-275

[4] J.O. Clemmesen, F.S. Larsen, J. Kondrup, B.A. Hansen, P. Ott Cerebral herniation in patients with acute liver failure is correlated with arterial ammonia concentration Hepatology, 29 (1999), pp. 648-653

[5] P. Mellergard Changes in human intracerebral temperature in response to different methods of brain cooling Neurosurgery, 31 (1992), pp. 671-677

[6] W.G. Bigelow, W.K. Lindsay, W.F. Greenwood Hypothermia; its possible role in cardiac surgery: an investigation of factors governing survival in dogs at low body temperatures Ann Surg, 132 (1950), pp. 849-866

[7] W.G. Bigelow, J.C. Callaghan, J.A. Hopps General hypothermia for experimental intracardiac surgery; the use of electrophrenic respirations, an artificial pacemaker for cardiac standstill, and radio-frequency rewarming in general hypothermia Trans Meet Am Surg Assoc Am Surg Assoc, 68 (1950), pp. 211-219

[8] P.L. Pemberton, J. Dinsmore The use of hypothermia as a method of neuroprotection during neurosurgical procedures and after traumatic brain injury: a survey of clinical practice in great Britain and Ireland Anaesthesia, 58 (2003), pp. 370-373

[9] J.P. Nolan, P.T. Morley, T.L. Vanden Hoek, R.W. Hickey, W.G. Kloeck, J. Billi et al. Therapeutic hypothermia after cardiac arrest: an advisory statement by the advanced life support task force of the international liaison committee on resuscitation Circulation, 108 (2003), pp. 118-121

[10] Hypothermia after Cardiac Arrest Study Group Mild therapeutic hypothermia to improve the neurologic outcome after cardiac arrest N Engl J Med, 346 (2002), pp. 549-556

The final publication is available at http://dx.doi.org/10.1016/i.jhep.2005.05.039 
Vaquero, J., Rose, C. \& Butterworth, R.F., 2005. Keeping cool in acute liver failure: rationale for the use of mild hypothermia. Journal of Hepatology, 43(6), p.1067-1077.

[11] S.A. Bernard, T.W. Gray, M.D. Buist, B.M. Jones, W. Silvester, G. Gutteridge et al. Treatment of comatose survivors of out-ofhospital cardiac arrest with induced hypothermia N Engl J Med, 346 (2002), pp. 557-563

[12] W.R. Henderson, V.K. Dhingra, D.R. Chittock, J.C. Fenwick, J.J. Ronco Hypothermia in the management of traumatic brain injury. A systematic review and meta-analysis Intensive Care Med, 29 (2003), pp. 1637-1644

[13] L.A. McIntyre, D.A. Fergusson, P.C. Hebert, D. Moher, J.S. Hutchison Prolonged therapeutic hypothermia after traumatic brain injury in adults: a systematic review J Am Med Assoc, 289 (2003), pp. 2992-2999

[14] R.S. Clark, P.M. Kochanek, D.W. Marion, J.K. Schiding, M. White, A.M. Palmer et al. Mild posttraumatic hypothermia reduces mortality after severe controlled cortical impact in rats J Cereb Blood Flow Metab, 16 (1996), pp. 253-261

[15] R. Busto, W.D. Dietrich, M.Y. Globus, I. Valdes, P. Scheinberg, M.D. Ginsberg Small differences in intraischemic brain temperature critically determine the extent of ischemic neuronal injury J Cereb Blood Flow Metab, 7 (1987), pp. 729-738

[16] G.L. Clifton, J.Y. Jiang, B.G. Lyeth, L.W. Jenkins, R.J. Hamm, R.L. Hayes Marked protection by moderate hypothermia after experimental traumatic brain injury J Cereb Blood Flow Metab, 11 (1991), pp. 114-121

[17] W.D. Dietrich, O. Alonso, R. Busto, M.Y. Globus, M.D. Ginsberg Post-traumatic brain hypothermia reduces histopathological damage following concussive brain injury in the rat Acta Neuropathol (Berlin), 87 (1994), pp. 250-258

[18] T. Shiozaki, H. Sugimoto, M. Taneda, H. Yoshida, A. Iwai, T. Yoshioka et al. Effect of mild hypothermia on uncontrollable intracranial hypertension after severe head injury J Neurosurg, 79 (1993), pp. 363-368

[19] G.L. Clifton, S. Allen, P. Barrodale, P. Plenger, J. Berry, S. Koch et al. A phase II study of moderate hypothermia in severe brain injury J Neurotrauma, 10 (1993), pp. 263-271

[20] D.W. Marion, L.E. Penrod, S.F. Kelsey, W.D. Obrist, P.M. Kochanek, A.M. Palmer et al. Treatment of traumatic brain injury with moderate hypothermia N Engl J Med, 336 (1997), pp. 540-546

[21] G.L. Clifton, E.R. Miller, S.C. Choi, H.S. Levin, S. McCauley, K.R. Smith Jr et al. Lack of effect of induction of hypothermia after acute brain injury N Engl J Med, 344 (2001), pp. 556-563

[22] G.L. Clifton, S.C. Choi, E.R. Miller, H.S. Levin, K.R. Smith Jr, J.P. Muizelaar et al. Intercenter variance in clinical trials of head trauma-experience of the national acute brain injury study: hypothermia J Neurosurg, 95 (2001), pp. 751-755

[23] A. Tateishi, Y. Soejima, Y. Taira, K. Nakashima, H. Fujisawa, E. Tsuchida et al. Feasibility of the titration method of mild hypothermia in severely head-injured patients with intracranial hypertension Neurosurgery, 42 (1998), pp. 1065-1069

[24] J. Jiang, M. Yu, C. Zhu Effect of long-term mild hypothermia therapy in patients with severe traumatic brain injury: 1-year follow-up review of 87 cases J Neurosurg, 93 (2000), pp. 546-549

[25] S. Schwab, S. Schwarz, M. Spranger, E. Keller, M. Bertram, W. Hacke Moderate hypothermia in the treatment of patients with severe middle cerebral artery infarction Stroke, 29 (1998), pp. 2461-2466

[26] L.P. Kammersgaard, B.H. Rasmussen, H.S. Jorgensen, J. Reith, U. Weber, T.S. Olsen Feasibility and safety of inducing modest hypothermia in awake patients with acute stroke through surface cooling: a case-control study: the copenhagen stroke study Stroke, 31 (2000), pp. 2251-2256

[27] S. Schwab, D. Georgiadis, J. Berrouschot, P.D. Schellinger, C. Graffagnino, S.A. Mayer Feasibility and safety of moderate hypothermia after massive hemispheric infarction Stroke, 32 (2001), pp. 2033-2035

[28] D. Georgiadis, S. Schwarz, R. Kollmar, S. Schwab Endovascular cooling for moderate hypothermia in patients with acute stroke: first results of a novel approach Stroke, 32 (2001), pp. 2550-2553

[29] D.W. Krieger, M.A. De Georgia, A. Abou-Chebl, J.C. Andrefsky, C.A. Sila, I.L. Katzan et al. Cooling for acute ischemic brain damage (cool aid): an open pilot study of induced hypothermia in acute ischemic stroke Stroke, 32 (2001), pp. 1847-1854

The final publication is available at http://dx.doi.org/10.1016/i.jhep.2005.05.039 
Vaquero, J., Rose, C. \& Butterworth, R.F., 2005. Keeping cool in acute liver failure: rationale for the use of mild hypothermia. Journal of Hepatology, 43(6), p.1067-1077.

[30] S. Gasser, N. Khan, Y. Yonekawa, H.G. Imhof, E. Keller Long-term hypothermia in patients with severe brain edema after poorgrade subarachnoid hemorrhage: feasibility and intensive care complications J Neurosurg Anesthesiol, 15 (2003), pp. 240-248

[31] M. Erecinska, M. Thoresen, I.A. Silver Effects of hypothermia on energy metabolism in Mammalian central nervous system J Cereb Blood Flow Metab, 23 (2003), pp. 513-530

[32] H.L. Rosomoff, D.A. Holaday Cerebral blood flow and cerebral oxygen consumption during hypothermia Am J Physiol, 179 (1954), pp. 85-88

[33] F.A. Welsh, R.E. Sims, V.A. Harris Mild hypothermia prevents ischemic injury in gerbil hippocampus J Cereb Blood Flow Metab, 10 (1990), pp. 557-563

[34] H. Minamisawa, M.L. Smith, B.K. Siesjo The effect of mild hyperthermia and hypothermia on brain damage following 5, 10, and 15 minutes of forebrain ischemia Ann Neurol, 28 (1990), pp. 26-33

[35] W.D. Dietrich, R. Busto, O. Alonso, M.Y. Globus, M.D. Ginsberg Intraischemic but not postischemic brain hypothermia protects chronically following global forebrain ischemia in rats J Cereb Blood Flow Metab, 13 (1993), pp. 541-549

[36] J.D. Michenfelder The interdependency of cerebral functional and metabolic effects following massive doses of thiopental in the dog Anesthesiology, 41 (1974), pp. 231-236

[37] L.A. Newberg, J.H. Milde, J.D. Michenfelder The cerebral metabolic effects of isoflurane at and above concentrations that suppress cortical electrical activity Anesthesiology, 59 (1983), pp. 23-28

[38] J.D. Michenfelder, R.A. Theye The effects of anesthesia and hypothermia on canine cerebral ATP and lactate during anoxia produced by decapitation Anesthesiology, 33 (1970), pp. 430-439

[39] A. Buchan, W.A. Pulsinelli Hypothermia but not the N-methyl-d-aspartate antagonist, MK-801, attenuates neuronal damage in gerbils subjected to transient global ischemia J Neurosci, 10 (1990), pp. 311-316

[40] C.J. Baker, S.T. Onesti, R.A. Solomon Reduction by delayed hypothermia of cerebral infarction following middle cerebral artery occlusion in the rat: a time-course study J Neurosurg, 77 (1992), pp. 438-444

[41] H.M. Bramlett, E.J. Green, W.D. Dietrich, R. Busto, M.Y. Globus, M.D. Ginsberg Posttraumatic brain hypothermia provides protection from sensorimotor and cognitive behavioral deficits J Neurotrauma, 12 (1995), pp. 289-298

[42] K. Nakashima, M.M. Todd, D.S. Warner The relation between cerebral metabolic rate and ischemic depolarization. A comparison of the effects of hypothermia, pentobarbital, and isoflurane Anesthesiology, 82 (1995), pp. 1199-1208

[43] J.A. Natale, L.G. D'Alecy Protection from cerebral ischemia by brain cooling without reduced lactate accumulation in dogs Stroke, 20 (1989), pp. 770-777

[44] K. Katsura, H. Minamisawa, A. Ekholm, J. Folbergrova, B.K. Siesjo Changes of labile metabolites during anoxia in moderately hypo- and hyperthermic rats: correlation to membrane fluxes of K+ Brain Res, 590 (1992), pp. 6-12

[45] R. Busto, M.Y. Globus, W.D. Dietrich, E. Martinez, I. Valdes, M.D. Ginsberg Effect of mild hypothermia on ischemia-induced release of neurotransmitters and free fatty acids in rat brain Stroke, 20 (1989), pp. 904-910

[46] C.J. Winfree, C.J. Baker, E.S. Connolly Jr, A.J. Fiore, R.A. Solomon Mild hypothermia reduces penumbral glutamate levels in the rat permanent focal cerebral ischemia model Neurosurgery, 38 (1996), pp. 1216-1222

[47] C.J. Baker, A.J. Fiore, V.I. Frazzini, T.F. Choudhri, G.P. Zubay, R.A. Solomon Intraischemic hypothermia decreases the release of glutamate in the cores of permanent focal cerebral infarcts Neurosurgery, 36 (1995), pp. 994-1001

[48] U.M. Illievich, M.H. Zornow, K.T. Choi, M.A. Strnat, M.S. Scheller Effects of hypothermia or anesthetics on hippocampal glutamate and glycine concentrations after repeated transient global cerebral ischemia Anesthesiology, 80 (1994), pp. 177-186

The final publication is available at http://dx.doi.org/10.1016/i.jhep.2005.05.039 
Vaquero, J., Rose, C. \& Butterworth, R.F., 2005. Keeping cool in acute liver failure: rationale for the use of mild hypothermia. Journal of Hepatology, 43(6), p.1067-1077.

[49] K. Nakashima, M.M. Todd Effects of hypothermia on the rate of excitatory amino acid release after ischemic depolarization Stroke, 27 (1996), pp. 913-918

[50] A.J. Baker, M.H. Zornow, M.R. Grafe, M.S. Scheller, S.R. Skilling, D.H. Smullin et al. Hypothermia prevents ischemia-induced increases in hippocampal glycine concentrations in rabbits Stroke, 22 (1991), pp. 666-673

[51] C. Berger, W.R. Schabitz, D. Georgiadis, T. Steiner, A. Aschoff, S. Schwab Effects of hypothermia on excitatory amino acids and metabolism in stroke patients: a microdialysis study Stroke, 33 (2002), pp. 519-524

[52] M.Y. Globus, O. Alonso, W.D. Dietrich, R. Busto, M.D. Ginsberg Glutamate release and free radical production following brain injury: effects of posttraumatic hypothermia J Neurochem, 65 (1995), pp. 1704-1711

[53] T. Morimoto, M.Y. Globus, R. Busto, E. Martinez, M.D. Ginsberg Simultaneous measurement of salicylate hydroxylation and glutamate release in the penumbral cortex following transient middle cerebral artery occlusion in rats J Cereb Blood Flow Metab, 16 (1996), pp. 92-99

[54] M.Y. Globus, R. Busto, B. Lin, H. Schnippering, M.D. Ginsberg Detection of free radical activity during transient global ischemia and recirculation: effects of intraischemic brain temperature modulation J Neurochem, 65 (1995), pp. 1250-1256

[55] C. Zhu, X. Wang, X. Cheng, L. Qiu, F. Xu, G. Simbruner et al. Post-ischemic hypothermia-induced tissue protection and diminished apoptosis after neonatal cerebral hypoxia-ischemia Brain Res, 996 (2004), pp. 67-75

[56] E. Eberspacher, C. Werner, K. Engelhard, M. Pape, A. Gelb, P. Hutzler et al. The effect of hypothermia on the expression of the apoptosis-regulating protein bax after incomplete cerebral ischemia and reperfusion in rats J Neurosurg Anesthesiol, 15 (2003), pp. $200-208$

[57] T. Shibano, Y. Morimoto, O. Kemmotsu, H. Shikama, K. Hisano, Y. Hua Effects of mild and moderate hypothermia on apoptosis in neuronal PC12 cells Br J Anaesth, 89 (2002), pp. 301-305

[58] M.A. Yenari, S. Iwayama, D. Cheng, G.H. Sun, M. Fujimura, Y. Morita-Fujimura et al. Mild hypothermia attenuates cytochrome c release but does not alter Bcl-2 expression or caspase activation after experimental stroke J Cereb Blood Flow Metab, 22 (2002), pp. $29-38$

[59] L. Xu, M.A. Yenari, G.K. Steinberg, R.G. Giffard Mild hypothermia reduces apoptosis of mouse neurons in vitro early in the cascade J Cereb Blood Flow Metab, 22 (2002), pp. 21-28

[60] C.M. Maier, K. Ahern, M.L. Cheng, J.E. Lee, M.A. Yenari, G.K. Steinberg Optimal depth and duration of mild hypothermia in a focal model of transient cerebral ischemia: effects on neurologic outcome, infarct size, apoptosis, and inflammation Stroke, 29 (1998), pp. 2171-2180

[61] H. Deng, H.S. Han, D. Cheng, G.H. Sun, M.A. Yenari Mild hypothermia inhibits inflammation after experimental stroke and brain inflammation Stroke, 34 (2003), pp. 2495-2501

[62] G.J. Wang, H.Y. Deng, C.M. Maier, G.H. Sun, M.A. Yenari Mild hypothermia reduces ICAM-1 expression, neutrophil infiltration and microglia/monocyte accumulation following experimental stroke Neuroscience, 114 (2002), pp. 1081-1090

[63] T. Toyoda, S. Suzuki, N.F. Kassell, K.S. Lee Intraischemic hypothermia attenuates neutrophil infiltration in the rat neocortex after focal ischemia-reperfusion injury Neurosurgery, 39 (1996), pp. 1200-1205

[64] R.J. Dempsey, D.J. Combs, M.E. Maley, D.E. Cowen, M.W. Roy, D.L. Donaldson Moderate hypothermia reduces postischemic edema development and leukotriene production Neurosurgery, 21 (1987), pp. 177-181

[65] H.S. Han, Y. Qiao, M. Karabiyikoglu, R.G. Giffard, M.A. Yenari Influence of mild hypothermia on inducible nitric oxide synthase expression and reactive nitrogen production in experimental stroke and inflammation J Neurosci, 22 (2002), pp. 3921-3928

[66] A. Kader, V.I. Frazzini, C.J. Baker, R.A. Solomon, R.R. Trifiletti Effect of mild hypothermia on nitric oxide synthesis during focal cerebral ischemia Neurosurgery, 35 (1994), pp. 272-277

The final publication is available at http://dx.doi.org/10.1016/i.jhep.2005.05.039 
Vaquero, J., Rose, C. \& Butterworth, R.F., 2005. Keeping cool in acute liver failure: rationale for the use of mild hypothermia. Journal of Hepatology, 43(6), p.1067-1077.

[67] E. Kumura, T. Yoshimine, M. Takaoka, T. Hayakawa, T. Shiga, H. Kosaka Hypothermia suppresses nitric oxide elevation during reperfusion after focal cerebral ischemia in rats Neurosci Lett, 220 (1996), pp. 45-48

[68] Q.S. Si, Y. Nakamura, K. Kataoka Hypothermic suppression of microglial activation in culture: inhibition of cell proliferation and production of nitric oxide and superoxide Neuroscience, 81 (1997), pp. 223-229

[69] I.T. Sutcliffe, H.A. Smith, D. Stanimirovic, J.S. Hutchison Effects of moderate hypothermia on IL-1 beta-induced leukocyte rolling and adhesion in pial microcirculation of mice and on proinflammatory gene expression in human cerebral endothelial cells J Cereb Blood Flow Metab, 21 (2001), pp. 1310-1319

[70] M. Aibiki, S. Maekawa, S. Ogura, Y. Kinoshita, N. Kawai, S. Yokono Effect of moderate hypothermia on systemic and internal jugular plasma IL-6 levels after traumatic brain injury in humans J Neurotrauma, 16 (1999), pp. 225-232

[71] W.D. Dietrich, R. Busto, M. Halley, I. Valdes The importance of brain temperature in alterations of the blood-brain barrier following cerebral ischemia J Neuropathol Exp Neurol, 49 (1990), pp. 486-497

[72] H. Karibe, G.J. Zarow, S.H. Graham, P.R. Weinstein Mild intraischemic hypothermia reduces postischemic hyperperfusion, delayed postischemic hypoperfusion, blood-brain barrier disruption, brain edema, and neuronal damage volume after temporary focal cerebral ischemia in rats J Cereb Blood Flow Metab, 14 (1994), pp. 620-627

[73] O.Z. Chi, X. Liu, H.R. Weiss Effects of mild hypothermia on blood-brain barrier disruption during isoflurane or pentobarbital anesthesia Anesthesiology, 95 (2001), pp. 933-938

[74] K. Kinoshita, K. Chatzipanteli, O.F. Alonso, M. Howard, W.D. Dietrich The effect of brain temperature on hemoglobin extravasation after traumatic brain injury J Neurosurg, 97 (2002), pp. 945-953

[75] P. Traber, M. DalCanto, D. Ganger, A.T. Blei Effect of body temperature on brain edema and encephalopathy in the rat after hepatic devascularization Gastroenterology, 96 (1989), pp. 885-891

[76] C. Rose, A. Michalak, M. Pannunzio, N. Chatauret, A. Rambaldi, R.F. Butterworth Mild hypothermia delays the onset of coma and prevents brain edema and extracellular brain glutamate accumulation in rats with acute liver failure Hepatology, 31 (2000), pp. $872-877$

[77] N. Chatauret, C. Rose, G. Therrien, R.F. Butterworth Mild hypothermia prevents cerebral edema and CSF lactate accumulation in acute liver failure Metab Brain Dis, 16 (2001), pp. 95-102

[78] J. Cordoba, J. Crespin, J. Gottstein, A.T. Blei Mild hypothermia modifies ammonia-induced brain edema in rats after portacaval anastomosis Gastroenterology, 116 (1999), pp. 686-693

[79] S. Schenker, K.S. Warren Effect of temperature variation on toxicity and metabolism of ammonia in mice J Lab Clin Med, 60 (1962), pp. 291-301

[80] R. Jalan, S.W. Damink, N.E. Deutz, A. Lee, P.C. Hayes Moderate hypothermia for uncontrolled intracranial hypertension in acute liver failure Lancet, 354 (1999), pp. 1164-1168

[81] R. Jalan, S.W. Olde Damink, N.E. Deutz, P.C. Hayes, A. Lee Moderate hypothermia in patients with acute liver failure and uncontrolled intracranial hypertension Gastroenterology, 127 (2004), pp. 1338-1346

[82] A. Whitelaw, S. Bridges, A. Leaf, D. Evans Emergency treatment of neonatal hyperammonaemic coma with mild systemic hypothermia Lancet, 358 (2001), pp. 36-38

[83] H.F. Welch, R. Affifi, C.L. Rosano Effect of hypothermia on blood ammonia formation Surgery, 50 (1961), pp. 390-394

[84] A.M. Keirle, J.J. McGloin, R.W. Buben, W.A. Altemeier Blood ammonia. Experimental and clinical reduction by hypothermia Arch Surg, 83 (1961), pp. 348-355

The final publication is available at http://dx.doi.org/10.1016/j.jhep.2005.05.039 
Vaquero, J., Rose, C. \& Butterworth, R.F., 2005. Keeping cool in acute liver failure: rationale for the use of mild hypothermia. Journal of Hepatology, 43(6), p.1067-1077.

[85] A.M. Keirle, C.M. Lewis, J.A. Helmsworth, W.A. Altemeier Hypothermic reduction of ammonia release into the circulation by the kidney Surg Forum, 15 (1964), pp. 102-103

[86] D.J. Johnson, D.C. Brooks, V.M. Pressler, N.R. Hulton, M.F. Colpoys, R.J. Smith et al. Hypothermic anesthesia attenuates postoperative proteolysis Ann Surg, 204 (1986), pp. 419-429

[87] H. Takahashi, R.C. Koehler, S.W. Brusilow, R.J. Traystman Inhibition of brain glutamine accumulation prevents cerebral edema in hyperammonemic rats Am J Physiol, 261 (1991), pp. H825-H829

[88] A. Martinez-Hernandez, K.P. Bell, M.D. Norenberg Glutamine synthetase: glial localization in brain Science, 195 (1977), pp. 1356-1358

[89] A.T. Blei, S. Olafsson, G. Therrien, R.F. Butterworth Ammonia-induced brain edema and intracranial hypertension in rats after portacaval anastomosis Hepatology, 19 (1994), pp. 1437-1444

[90] J. Cordoba, J. Gottstein, A.T. Blei Glutamine, myo-inositol, and organic brain osmolytes after portocaval anastomosis in the rat: implications for ammonia-induced brain edema Hepatology, 24 (1996), pp. 919-923

[91] M. Swain, R.F. Butterworth, A.T. Blei Ammonia and related amino acids in the pathogenesis of brain edema in acute ischemic liver failure in rats Hepatology, 15 (1992), pp. 449-453

[92] C. Zwingmann, N. Chatauret, D. Leibfritz, R.F. Butterworth Selective increase of brain lactate synthesis in experimental acute liver failure: results of a [H-C] nuclear magnetic resonance study Hepatology, 37 (2003), pp. 420-428

[93] A.M. Mans, M.R. DeJoseph, R.A. Hawkins Metabolic abnormalities and grade of encephalopathy in acute hepatic failure J Neurochem, 63 (1994), pp. 1829-1838

[94] J. Peeling, L. Shoemaker, T. Gauthier, A. Benarroch, G.R. Sutherland, G.Y. Minuk Cerebral metabolic and histological effects of thioacetamide-induced liver failure Am J Physiol, 265 (1993), pp. G572-G578

[95] C. Chung, J. Gottstein, A.T. Blei Indomethacin prevents the development of experimental ammonia-induced brain edema in rats after portacaval anastomosis Hepatology, 34 (2001), pp. 249-254

[96] N. Chatauret, C. Zwingmann, C. Rose, D. Leibfritz, R.F. Butterworth Effects of hypothermia on brain glucose metabolism in acute liver failure: a H/C-nuclear magnetic resonance study Gastroenterology, 125 (2003), pp. 815-824

[97] C. Zwingmann, N. Chatauret, C. Rose, D. Leibfritz, R.F. Butterworth Selective alterations of brain osmolytes in acute liver failure: protective effect of mild hypothermia Brain Res, 999 (2004), pp. 118-123

[98] F. Tofteng, L. Jorgensen, B.A. Hansen, P. Ott, J. Kondrup, F.S. Larsen Cerebral microdialysis in patients with fulminant hepatic failure Hepatology, 36 (2002), pp. 1333-1340

[99] A. Michalak, C. Rose, J. Butterworth, R.F. Butterworth Neuroactive amino acids and glutamate (NMDA) receptors in frontal cortex of rats with experimental acute liver failure Hepatology, 24 (1996), pp. 908-913

[100] R.J. De Knegt, S.W. Schalm, C.C. van der Rijt, D. Fekkes, E. Dalm, I. Hekking-Weyma Extracellular brain glutamate during acute liver failure and during acute hyperammonemia simulating acute liver failure: an experimental study based on in vivo brain dialysis J Hepatol, 20 (1994), pp. 19-26

[101] D.K. Bosman, N.E. Deutz, M.A. Maas, H.M. van Eijk, J.J. Smit, J.G. de Haan et al. Amino acid release from cerebral cortex in experimental acute liver failure, studied by in vivo cerebral cortex microdialysis J Neurochem, 59 (1992), pp. 591-599

[102] H. Chan, R.F. Butterworth Evidence for an astrocytic glutamate transporter deficit in hepatic encephalopathy Neurochem Res, 24 (1999), pp. 1397-1401

[103] H. Chan, A.S. Hazell, P. Desjardins, R.F. Butterworth Effects of ammonia on glutamate transporter (GLAST) protein and mRNA in cultured rat cortical astrocytes Neurochem Int, 37 (2000), pp. 243-248

The final publication is available at http://dx.doi.org/10.1016/i.jhep.2005.05.039 
Vaquero, J., Rose, C. \& Butterworth, R.F., 2005. Keeping cool in acute liver failure: rationale for the use of mild hypothermia. Journal of Hepatology, 43(6), p.1067-1077.

[104] C. Rose Increased extracellular brain glutamate in acute liver failure: decreased uptake or increased release? Metab Brain Dis, 17 (2002), pp. 251-261

[105] A.S. Bender, A. Schousboe, W. Reichelt, M.D. Norenberg Ionic mechanisms in glutamate-induced astrocyte swelling: role of K+ influx J Neurosci Res, 52 (1998), pp. 307-321

[106] P.H. Chan, L. Chu, S. Chen Effects of MK-801 on glutamate-induced swelling of astrocytes in primary cell culture J Neurosci Res, 25 (1990), pp. 87-93

[107] A.S. Bender, M.D. Norenberg The role of K+ influx on glutamate induced astrocyte swelling: effect of temperature Acta Neurochir Suppl (Wien), 60 (1994), pp. 28-30

[108] B.A. Vogels, M.A. Maas, J. Daalhuisen, G. Quack, R.A. Chamuleau Memantine, a noncompetitive NMDA receptor antagonist improves hyperammonemia-induced encephalopathy and acute hepatic encephalopathy in rats Hepatology, 25 (1997), pp. 820827

[109] F. Schliess, B. Gorg, R. Fischer, P. Desjardins, H.J. Bidmon, A. Herrmann et al. Ammonia induces MK-801-sensitive nitration and phosphorylation of protein tyrosine residues in rat astrocytes Fed Am Soc Exp Biol J, 16 (2002), pp. 739-741

[110] V.L. Rao, R.M. Audet, R.F. Butterworth Selective alterations of extracellular brain amino acids in relation to function in experimental portal-systemic encephalopathy: results of an in vivo microdialysis study J Neurochem, 65 (1995), pp. 1221-1228

[111] F.S. Larsen, B. Adel Hansen, F. Pott, E. Ejlersen, N.H. Secher, O.B. Paulson et al. Dissociated cerebral vasoparalysis in acute liver failure. A hypothesis of gradual cerebral hyperaemia J Hepatol, 25 (1996), pp. 145-151

[112] G. Strauss, B.A. Hansen, G.M. Knudsen, F.S. Larsen Hyperventilation restores cerebral blood flow autoregulation in patients with acute liver failure J Hepatol, 28 (1998), pp. 199-203

[113] S. Aggarwal, D. Kramer, H. Yonas, W. Obrist, Y. Kang, M. Martin et al. Cerebral hemodynamic and metabolic changes in fulminant hepatic failure: a retrospective study Hepatology, 19 (1994), pp. 80-87

[114] S. Durham, H. Yonas, S. Aggarwal, J. Darby, D. Kramer Regional cerebral blood flow and CO2 reactivity in fulminant hepatic failure J Cereb Blood Flow Metab, 15 (1995), pp. 329-335

[115] J.A. Wendon, P.M. Harrison, R. Keays, R. Williams Cerebral blood flow and metabolism in fulminant liver failure Hepatology, 19 (1994), pp. 1407-1413

[116] F.S. Larsen, J. Wendon Brain edema in liver failure: basic physiologic principles and management Liver Transpl, 8 (2002), pp. 983-989

[117] S. Aggarwal, H. Yonas, Y. Kang, M. Martin, D. Kramer, W.D. Obrist et al. Relationship of cerebral blood flow and cerebral swelling to outcome in patients with acute fulminant hepatic failure Transplant Proc, 23 (1991), pp. 1978-1979

[118] C. Chung, J. Vaquero, J. Gottstein, A.T. Blei Vasopressin accelerates experimental ammonia-induced brain edema in rats after portacaval anastomosis J Hepatol, 39 (2003), pp. 193-199

[119] R. Jalan, S.W. Olde Damink, N.E. Deutz, P.C. Hayes, A. Lee Restoration of cerebral blood flow autoregulation and reactivity to carbon dioxide in acute liver failure by moderate hypothermia Hepatology, 34 (2001), pp. 50-54

[120] R. Jalan, S.W. Olde Damink, N.E. Deutz, N.A. Davies, O.J. Garden, K.K. Madhavan et al. Moderate hypothermia prevents cerebral hyperemia and increase in intracranial pressure in patients undergoing liver transplantation for acute liver failure Transplantation, 75 (2003), pp. 2034-2039

[121] S.L. Nyberg, F.B. Cerra, R. Gruetter Brain lactate by magnetic resonance spectroscopy during fulminant hepatic failure in the dog Liver Transpl Surg, 4 (1998), pp. 158-165

The final publication is available at http://dx.doi.org/10.1016/i.jhep.2005.05.039 
Vaquero, J., Rose, C. \& Butterworth, R.F., 2005. Keeping cool in acute liver failure: rationale for the use of mild hypothermia. Journal of Hepatology, 43(6), p.1067-1077.

[122] J.C. Lai, A.J. Cooper Brain alpha-ketoglutarate dehydrogenase complex: kinetic properties, regional distribution, and effects of inhibitors J Neurochem, 47 (1986), pp. 1376-1386

[123] 0.H. Lowry, J.V. Passonneau Kinetic evidence for multiple binding sites on phosphofructokinase J Biol Chem, 241 (1966), pp. 2268-2279

[124] N. Rolando, J. Wade, M. Davalos, J. Wendon, J. Philpott-Howard, R. Williams The systemic inflammatory response syndrome in acute liver failure Hepatology, 32 (2000), pp. 734-739

[125] J. Vaquero, J. Polson, C. Chung, I. Helenowski, F.V. Schiodt, J. Reisch et al. Infection and the progression of hepatic encephalopathy in acute liver failure Gastroenterology, 125 (2003), pp. 755-764

[126] Y. Takada, S. Ishiguro, K. Fukunaga, M. Gu, H. Taniguchi, K.I. Seino et al. Increased intracranial pressure in a porcine model of fulminant hepatic failure using amatoxin and endotoxin J Hepatol, 34 (2001), pp. 825-831

[127] R. Jalan, A. Pollok, S.H. Shah, K. Madhavan, K.J. Simpson Liver derived pro-inflammatory cytokines may be important in producing intracranial hypertension in acute liver failure J Hepatol, 37 (2002), pp. 536-538

[128] N. Rolando, A. Ellis, J.A. D De Groote, J. Wendon, R. Williams Correlation of serial cytokine levels with progression to coma (grade IV) in patients with acute liver failure (ALF) Hepatology, 22 (1995), p. 366A

[129] R. Jalan, S.W. Olde Damink, P.C. Hayes, N.E. Deutz, A. Lee Pathogenesis of intracranial hypertension in acute liver failure: inflammation, ammonia and cerebral blood flow J Hepatol, 41 (2004), pp. 613-620

[130] A.S. Bender, I.V. Rivera, M.D. Norenberg Tumor necrosis factor-alpha induces astrocyte swelling Trans Am Neurochem, 23 (1992), p. 113 [Abstract]

[131] A.J. Ellis, J.A. Wendon, R. Williams Subclinical seizure activity and prophylactic phenytoin infusion in acute liver failure: a controlled clinical trial Hepatology, 32 (2000), pp. 536-541

[132] V. Bhatia, Y. Batra, S.K. Acharya Prophylactic phenytoin does not improve cerebral edema or survival in acute liver failurea controlled clinical trial J Hepatol, 41 (2004), pp. 89-96

[133] M. Baldwin, L.L. Frost Effect of hypothermia on epileptiform activity in the primate temporal lobe Science, 124 (1956), pp. 931-932

[134] Z. Liu, A. Gatt, M. Mikati, G.L. Holmes Effect of temperature on kainic acid-induced seizures Brain Res, 631 (1993), pp. 51-58

[135] M. Belanger, P. Desjardins, N. Chatauret, R.F. Butterworth Loss of expression of glial fibrillary acidic protein in acute hyperammonemia Neurochem Int, 41 (2002), pp. 155-160

[136] P. Desjardins, M. Belanger, R.F. Butterworth Alterations in expression of genes coding for key astrocytic proteins in acute liver failure J Neurosci Res, 66 (2001), pp. 967-971

[137] K. Knecht, A. Michalak, C. Rose, J.D. Rothstein, R.F. Butterworth Decreased glutamate transporter (GLT-1) expression in frontal cortex of rats with acute liver failure Neurosci Lett, 229 (1997), pp. 201-203

[138] Y. Itzhak, A. Roig-Cantisano, R.S. Dombro, M.D. Norenberg Acute liver failure and hyperammonemia increase peripheraltype benzodiazepine receptor binding and pregnenolone synthesis in mouse brain Brain Res, 705 (1995), pp. 345-348

[139] G. Song, V.K. Dhodda, A.T. Blei, R.J. Dempsey, V.L. Rao GeneChip analysis shows altered mRNA expression of transcripts of neurotransmitter and signal transduction pathways in the cerebral cortex of portacaval shunted rats J Neurosci Res, 68 (2002), pp. $730-737$

[140] U. Warskulat, B. Gorg, H.J. Bidmon, H.W. Muller, F. Schliess, D. Haussinger Ammonia-induced heme oxygenase-1 expression in cultured rat astrocytes and rat brain in vivo Glia, 40 (2002), pp. 324-336

The final publication is available at http://dx.doi.org/10.1016/i.jhep.2005.05.039 
Vaquero, J., Rose, C. \& Butterworth, R.F., 2005. Keeping cool in acute liver failure: rationale for the use of mild hypothermia. Journal of Hepatology, 43(6), p.1067-1077.

[141] M. Belanger, P. Desjardins, N. Chatauret, C. Rose, R.F. Butterworth Mild hypothermia prevents brain edema and attenuates up-regulation of the astrocytic benzodiazepine receptor in experimental acute liver failure J Hepatol, 42 (2005), pp. 694-699

[142] R. Jalan Intracranial hypertension in acute liver failure: pathophysiological basis of rational management Semin Liver Dis, 23 (2003), pp. 271-282

[143] P.M. Harrison, R. Keays, G.P. Bray, G.J. Alexander, R. Williams Improved outcome of paracetamol-induced fulminant hepatic failure by late administration of acetylcysteine Lancet, 335 (1990), pp. 1572-1573

[144] P.M. Harrison, J.A. Wendon, A.E. Gimson, G.J. Alexander, R. Williams Improvement by acetylcysteine of hemodynamics and oxygen transport in fulminant hepatic failure N Engl J Med, 324 (1991), pp. 1852-1857

[145] E.F. Wijdicks, S.L. Nyberg Propofol to control intracranial pressure in fulminant hepatic failure Transplant Proc, 34 (2002), pp. $1220-1222$

[146] F. Tofteng, F.S. Larsen The effect of indomethacin on intracranial pressure, cerebral perfusion and extracellular lactate and glutamate concentrations in patients with fulminant hepatic failure J Cereb Blood Flow Metab, 24 (2004), pp. 798-804

[147] N. Murphy, G. Auzinger, W. Bernel, J. Wendon The effect of hypertonic sodium chloride on intracranial pressure in patients with acute liver failure Hepatology, 39 (2004), pp. 464-470

[148] S.C. Chen, W.R. Hewitt, F.D. Watanabe, S. Eguchi, E. Kahaku, Y. Middleton et al. Clinical experience with a porcine hepatocytebased liver support system Int J Artif Organs, 19 (1996), pp. 664-669

[149] T.M. Khalili, A. Navarro, P. Ting, Y. Kamohara, N. Arkadopoulos, B.A. Solomon et al. Bioartificial liver treatment prolongs survival and lowers intracranial pressure in pigs with fulminant hepatic failure Artif Organs, 25 (2001), pp. 566-570

[150] D.R. Roberts, D. Manas Induced hypothermia in the management of cerebral oedema secondary to fulminant liver failure Clin Transplant, 13 (1999), pp. 545-547

[151] O. Detry, N. Arkadopoulos, P. Ting, E. Kahaku, J. Margulies, W. Arnaout et al. Intracranial pressure during liver transplantation for fulminant hepatic failure Transplantation, 67 (1999), pp. 767-770

[152] R. Keays, D. Potter, J. O'Grady, T. Peachey, G. Alexander, R. Williams Intracranial and cerebral perfusion pressure changes before, during and immediately after orthotopic liver transplantation for fulminant hepatic failure Q J Med, 79 (1991), pp. 425433

[153] F.S. Larsen, E. Ejlersen, J.O. Clemmesen, P. Kirkegaard, B.A. Hansen Preservation of cerebral oxidative metabolism in fulminant hepatic failure: an autoregulation study Liver Transpl Surg, 2 (1996), pp. 348-353

[154] G. Strauss, B.A. Hansen, P. Kirkegaard, A. Rasmussen, A. Hjortrup, F.S. Larsen Liver function, cerebral blood flow autoregulation, and hepatic encephalopathy in fulminant hepatic failure Hepatology, 25 (1997), pp. 837-839

[155] A. Schubert Side effects of mild hypothermia J Neurosurg Anesthesiol, 7 (1995), pp. 139-147

[156] K.H. Polderman Application of therapeutic hypothermia in the intensive care unit. Opportunities and pitfalls of a promising treatment modality. Part 2: practical aspects and side effects Intensive Care Med, 30 (2004), pp. 757-769

[157] A.T. Blei Hypothermia for hypertension Lancet, 354 (1999), p. 2082

[158] K. Ishikawa, H. Tanaka, T. Shiozaki, M. Takaoka, H. Ogura, M. Kishi et al. Characteristics of infection and leukocyte count in severely head-injured patients treated with mild hypothermia J Trauma, 49 (2000), pp. 912-922

[159] T. Shiozaki, T. Hayakata, M. Taneda, Y. Nakajima, N. Hashiguchi, S. Fujimi et al. A multicenter prospective randomized controlled trial of the efficacy of mild hypothermia for severely head injured patients with low intracranial pressure. Mild hypothermia study group in Japan J Neurosurg, 94 (2001), pp. 50-54

The final publication is available at http://dx.doi.org/10.1016/i.jhep.2005.05.039 
Vaquero, J., Rose, C. \& Butterworth, R.F., 2005. Keeping cool in acute liver failure: rationale for the use of mild hypothermia. Journal of Hepatology, 43(6), p.1067-1077.

[160] A. Ferrara, J.D. MacArthur, H.K. Wright, I.M. Modlin, M.A. McMillen Hypothermia and acidosis worsen coagulopathy in the patient requiring massive transfusion Am J Surg, 160 (1990), pp. 515-518

[161] M. Aibiki, S. Maekawa, S. Yokono Moderate hypothermia improves imbalances of thromboxane A2 and prostaglandin I2 production after traumatic brain injury in humans Crit Care Med, 28 (2000), pp. 3902-3906

[162] S.H. Caldwell, C. Chang, B.G. Macik Recombinant activated factor VII (rFVIIa) as a hemostatic agent in liver disease: a break from convention in need of controlled trials Hepatology, 39 (2004), pp. 592-598

[163] N. Rolando, M. Clapperton, J. Wade, J. Wendon Administering granulocyte colony-stimulating factor to acute liver failure patients corrects neutrophil defects Eur J Gastroenterol Hepatol, 12 (2000), pp. 1323-1328

[164] A. Kato, S. Singh, K.R. McLeish, M.J. Edwards, A.B. Lentsch Mechanisms of hypothermic protection against ischemic liver injury in mice

Am J Physiol Gastrointest Liver Physiol, 282 (2002), pp. G608-G616

[165] J. Vaquero, M. Belanger, J. Cote, R.F. Butterworth Mild hypothermia attenuates acetaminophen-induced hepatic necrosis in mice: therapeutic implications Hepatology, 40 (2004), p. $220 \mathrm{~A}$

[166] T. Fu, A.T. Blei, N. Takamura, T. Lin, D. Guo, H. Li et al. Hypothermia inhibits Fas-mediated apoptosis of primary mouse hepatocytes in culture Cell Transplant, 13 (2004), pp. 667-676

[167] S.J. Munoz Hypothermia may impair hepatic regeneration in acute liver failure Gastroenterology, 128 (2005), pp. 11431144

[168] M. Kato, R.D. Hughes, R.T. Keays, R. Williams Electron microscopic study of brain capillaries in cerebral edema from fulminant hepatic failure Hepatology, 15 (1992), pp. 1060-1066

The final publication is available at http://dx.doi.org/10.1016/i.jhep.2005.05.039 